doi: 10.18575/msrs.sm.e.17.20

UDCK 616.61-089.843

COBISS.RS-ID 6836760

\title{
Treatment of Transplant Patient For Non-Transplant Surgery
}

\begin{abstract}
We present the case of a successfully operated patient with a kidney transplanted due to varicose veins of the right leg. A renal transplantation was performed eight years ago in a regional transplant center and since then, the patient has regularly been under nephrologist controls on immunosuppressive therapy with the proper function of the transplanted organ. The surgical procedure for vascular intervention was performed under spinal anesthesia, without perioperative complications. On the fourth postoperative day, the patient was discharged. The goal of this paper is to describe perioperative assessment and tretmant of the patients with a transplanted kidney.
\end{abstract}

Key words: organ transplants, non-transplant surgery

(Scr Med 2017:48:137-140)
Dragan Švraka ${ }^{1}$ Anita Đurđević Šrraka ${ }^{2}$, Slaviša Milanović ${ }^{3}$, Dragan Rakanović ${ }^{1}$

${ }^{1}$ UCC RS Banja Luka, Clinic for Anesthesiology and Intensive Care ${ }^{2}$ PHI Hospital Gradiška, Department for Anesthesiology, Reanimation and Intensive Care ${ }^{3}$ UCC RS Banja Luka, Department for Vascular Surgery

Contact address:

Dragan Švaka

Clinic for Anesthesiology and

Intensive Care,

University Clinical center of

Republic of Srpska

Street address: Zdravka Korde 1

7800 Banja Luka,

Republic of Srpska

Bosnia i Herzegovina

e-mail: dragan.svraka@kc-bl.com

phone number: $+387-65-463-723$

Submitted: May $8^{\text {th }}, 2017$

Accepted: June 12th, 2017

\section{Introduction}

Anesthesiologists and surgeons who do not work in transplant centers often meet patients with transplanted organs who need some surgery. Every year a number of successfully performed organ transplantation is increasing. Over 140 ooo people live with functional kidney transplant. Every year in the USA, > 16000 patients receive organ transplants and this number is expected to increase every year. ${ }^{1}$ As the treatment of transplant patients is constantly improving, an annual survival rate increases up to $80-90 \%$ and has a growing trend. Because of these trends, each year there is an increasing number of transplant patients who require urgent or elective non-transplant surgical procedures. In this paper, along with the case report, we will explain the treatment of a transplant patient for non-transplant surgery with a special reference to renal transplant patients.

\section{Case report}

A 47-year-old patient is admitted to the Department of Vascular Surgery, University Clinical Center in Banja Luka for elective surgery of varicose veins of the right leg. Eight years ago, in a regional transplant center, the patient had a kidney transplantation from one living donor (a mother).

The patient feels good continually, without any complaints, stable graft function is under nephrologist controls on the regular basis. The patient is under regular immunosuppressive therapy (Tacrolimus 1.5mgx2, CellCept 50omg+50omg, Pronison 7.5mg on the second day), Aspirin 100mg and Ranisan 150mgx2.

Preoperative laboratory findings: WBC $6.7 / \mathrm{mm} 3$; RBC 5.58/mm3; Hgb 163 g/L; Hct 0.49; Plt 197/mm3; urea $5.2 \mathrm{mmol} / \mathrm{L}$, creatinine $131 \mu \mathrm{mol} / \mathrm{L} ; \mathrm{Na} 147 \mathrm{mmol} / \mathrm{l}$; K 5.5 $\mathrm{mmol} / \mathrm{L}$; normal urine findings, ECG and chest X rays in order. He comes with preoperative instructions of the attending nephrologist. 
After standard preoperative preparations, the patients is observed by the anesthesiologist and operative risks are estimated according to the ASA II. According to the recommendations of a regional transplant center nephrologist, Prograf therapy is continued without changes while two days before the surgery, CellCept therapy is reduced to 2x 250mg and Pronison therapy increased to $20 \mathrm{mg}$.

Preoperativly, twelve hours before the surgery, o,4 Clexan sc. administered, and 1,2g Amoxiclav iv one hour prior to the surgery. Upon the entering the OR and after placing IV cannula and standard hemodynamic and respiratory monitoring, the patient is administered with a "single shoot" spinal anesthesia technique, $3 \mathrm{ml}$ of $0.5 \%$ bupivacain with $25 \mathrm{G}$ spinal needle at the $\mathrm{L}_{3}-\mathrm{L} 4$ level. The following surgery is performed: crosectomia, ligatura et striping VSM l.dex.cum phlebectomia cruris l.dex. During the surgery, the patient is hemodinamically and respiratory stable. $1100 \mathrm{ml}$ of crystalloid solutions were administered intraoperatively.

Postoperatively, the patient is transferred to the Department of Vascular Surgery. Three hours postoperatively, the patient is mobilised, without hemodynamic or respiratory changes and the oral administration diet starts. On the forth postoperative day, in good general condition and with the required immunosuppressive therapy (2x1,5mg Prograf, 2x250mg CellCept, 7,5mg Pronison on the second day), the patient is discharged.

\section{Discussion}

Preoperative assessment of organ transplant patients for non-transplant surgery should be focused on the function of the transplanted organ, sings of rejection and infection and function of other organs, particularly those who may have diminished functions, whether due to immunosuppressive therapy or because of dysfunction in a transplanted organ. ${ }^{1}$

Patients with a transplanted organ are always under some kind of immunosuppression regimes.Immunosuppressive drugs can modify the pharmacological properties of many drugs used in anesthesia menagment. Data on the effects of general anesthesia on IV cyclosporine or tacrolimus pharmacokinetics in humans are limited. ${ }^{1}$

Rejection and infection separately or in combination are the most serious complications of non-transplant surgery in patients with a transplant organ, which increases the risk of morbidity and mortality of those patients.

Rejection is an expected side effect of transplantation and up to $30 \%$ of people who receive a kidney transplant experience some degree of rejection. Most rejection occurs within six months after transplantation, but can occur at any time, even years later. ${ }^{2}$ Rejection results in the progressive deterioration of organ function tests, it is main cause of late mortality in transplant patients ${ }^{3}$ and it should be suspected if functional assays of the transplanted organ are abnormal. The presence of rejection should always be ruled out preoperatively. In our patient, preoperative renal function tests were normal. There is evidence that patients who undergo surgical procedures during the period of rejection have a higher morbidity. ${ }^{4}$

Our patient was operated as elective, and according to the clinical status and laboratory findings had no sings of any infectious process. The presence of infection should always be evaluated and excluded preoperatively. Immunosuppression which the patient is subjected to is certainly an important factor for the development of infection. Reducing the dose of immunosuppressive drugs in the perioperative period may increase the risk of rejection. In therapeutic dosages, cyclosporin and tacrolimus, it may cause a dose-dependent reduction in renal blood flow and the level of glomerular filtration rate, due to renal vasoconstriction. ${ }^{4}$ Therefore, we consulted the nephrologist from regional transplant center and he proposed the scheme of immunosuppressive therapy administration, which we used.

Different anesthetic techniques of general or regional anesthesia can be successfully used in patients with an transplanted organ.

Except for LMWH and antibiotics, we did not use any other premedication with our patient, even though standard premedication drugs can be used as in nontransplant patients. The only limiting factor may be a bad function of the transplanted organ. When the liver and renal function are correct, there are no contraindications for the use of any anesthetics. ${ }^{5}$ In our case, corticosteroid dosage was increased as recommended and additional dose of corticosteroids was not used. Additional "stress-coverage" dose of corticosteroids probably is not necessary, except in transplant patients who have recently abolished corticosteroid therapy. ${ }^{1}$

Selection of perioperative monitoring is determined by the type of surgery, type of anesthesia techniques and the availability of equipment. The main task in patients with a transplanted kidney is to maintain renal perfusion by maintaining an adequate circulating volume. Monitoring of central venous pressure is useful to prevent prerenal damage of transplanted kidney, but a central venous catheter should be set using strict aseptic techniques. 
We compensated circulatory volume according to the calculation of the length of preoperative abstinence from food and drink. We did not use invasive monitoring because our patient had no large intraoperative fluid loss. Invasive monitoring is not indicated only on the basis that it is a patient with a transplanted organ. ${ }^{6}$ Invasive monitoring should be considered on the principle of riskbenefit ratio. ${ }^{7}$

Regional anesthetic procedures, such as neuroaxial or peripheral nerve blockade have become a fundamental element of modern anesthesia. In immunocompromised patients, regional anesthesia (peripherial nerve block and neuroaxial block) can be useful and should be considered in order to enable appropriate management of pain and reduce the risk for this patients. ${ }^{8}$ The operation of our patient was performed under regional anesthesia, as preferred by the organ transplant centers because it provides better perfusion of organs. ${ }^{8}$ Although the combined spinal-epidural anesthesia is more adequate choice, we were afraid of infection and other complications, although most of the available literature does not specify a higher incidence of these complications.

\section{Conclusion}

A selection of anesthesia procedure in case of surgery in patients with a transplanted organ are greatly facilitated if it comes to elective surgery which gives us enough time to consider the function of the graft and based on that, the general condition of the patient and type of surgery, choose the most appropriate anesthetic procedure. Consultations with the reference transplant centers offer the possibility for these patients to be surgically managed in medical institutions that are not involved in transplant surgery.

\section{References}

1. Ja Kostopanagiotou G., Smyrniotis V., Arkadopoulus N., Theodaraki K., Papadimitriou L., Papadimitriou J. Anesthetic and perioperative management of adult transplant recipients in nontransplant surgery. Anasth Analg 1999; 89: 613-22.

https://doi.org/10.1097/00000539-199909000-00013 https://doi.org/10.1213/00000539-199909000-00013

2. http://www.surgery.ucsf.edu/conditions-procedures/ kidny-transplantation.aspx

3. Howard TK. Postoperative intensive care managment of the adult. In: Busuttili RW, Klintmalm GB,eds. Transplantation of the liver. Philadelphia: WB Saunders, 1996: 551-63.

4. Black AE. Anesthesia for pediatric patients who have had a transplant. Int Anesthesiol Clin 1995; 33: 107-23. https://doi.org/10.1097/00004311-199503320-00008 PMid:7657376

5. Csete M, Sipher MJ. Managment of the transplant patient for nontransplant procedures. Adv Anesth 1994; 11:407-31.

6. Csete M, Banks D, Manecke G, Glas K. Transplant anesthesia In: Barash P.G, Cullen B.F, Stoelting R.K, Cahalan M.K, Christine Stock M, Ortega R. Handbook of Clinical Anesthesia. Philadelphia: Wolters Kluver Healt/ Lippincott Williams\&Wilkins 2013:1459-

7. Zeyneloglu P., Pirat A., Sulemanji D., Torgay A., Karakayali H., Arslan G. Perioperative anesthetic management for recipients of orthotopic liver transplant undergoing nontransplant surgery. Expl Clin Transplant 2007; 5(2): 690-2. PMid:18194123

8. Gronwald C., Vowinkel T., Hahnenkamp K.. Regional anesthetic procedures in immunosuppressed patients: risk of infection. Curr Opin Ansthesiol 2011; 24:698-704. https://doi.org/10.1097/ACO.obo13e32834cd2fo PMid:21986352 


\section{Zbrinjavanje transplantiranog bolesnika za netransplantacionu hirurgiju}

\section{SAŽETAK}

Prikazujemo slučaj uspješno operisanog pacijenta sa transplantiranim bubregom zbog proširenih vena desne noge. Pacijentu je bubreg transplantiran prije osam godina u regionalnom transplantacionom centru i od tada je pod redovnim kontrolama nefrologa na imunosupresivnoj terapiji, uredne funkcije transplantiranog organa. Operativni zahvat je urađen u uslovima spinalne anestezije. Perioparativni tok bez komplikacija. Četvrtog postoperativnog dana otpušten je na kućno liječenje. U radu je razmotrena preoperativna priprema i intraoperativno postupanje sa bolesnicima kod kojih je transplantiran bubreg.

Ključne riječi: transplantacija organa, netransplantaciona hirurgija 